\title{
Solidification of the Aluminium Alloy in the Mold
}

Blanka Skočilasová1 ${ }^{,}$Jan Skočilas ${ }^{2}$

${ }^{1}$ J. E. Purkyne University in Usti nad Labem, Faculty of Production Technology and Management, Pasteurova 3334/7, 40096 Usti nad Labem, Czech Republic. E-mail: skocilasova@fvtm.ujep.cz

${ }^{2}$ Czech Technical University in Prague, Faculty of Mechanical Engineering, Department of Process Engineering, Technická 4, 16607 Praha 6, Czech Republic. E-mail: jan.skocilas@fs.cvut.cz

The process of the aluminum alloy casting was investigated. Two materials of the mold were used to observe the effect of thermal conductivity on the time of the solidification. The simulation of the process was conducted in the CFD software respecting the radiation. The results of the designed model of the casting process were compared with the analytical solution obtained from literature.

Keywords: aluminum alloy, simulation, solidification, mold

\section{Acknowledgements}

This work was supported by SGA (Students Grant Agency) Jan Evangelista Purkyně University in Ústí nad Labem.

\section{References}

[1] ASKELAND, D., PHULE, P., P. (2004). Essentials of Materials Science and Engineering. Thomson, Ontario, Canada.

[2] DEGARMO, E., P., BLACK, J. T., KOHSER, R. (2003). Materials and Processes in Manufacturing (9th. Ed.) Wiley.

[3] CHVORINOV, N. (1954). Krystalizace a nestejnorodost ocelí. NČSAV, Praha, 383 s.

[4] KAVIČKA, F., STRÁNSKÝ, K., SEKANINA, B., ŠTĚTINA J. (2009). Numerical model of Crystallization of Pure Aluminium, in: Hutnické listy č. 5/2009, roč. LXII, str. 68 - 74

[5] LENHARD, R., KADUCHOVÁ, K., JANDAČKA, J. (2014). Numerical simulation in indirectly heated hot water heater, Adv. Material Research, 875-877 pp. 1693-1697.

[6] LIOTTI, E., PREVITALI, B. (2006). Study of the validity of the Niyama criterionfunction applied to the aloy AlSi7Mg, in: La metallurgia italiana, No. 9/2006, p. 33-37.

[7] MICHNA, S., NÁPRSTKOVÁ, N. (2012). Research into the causes cracking of aluminum alloys of $\mathrm{Al}-\mathrm{Cu}$ during mechanical machining, Manufacturing Technology Vol. 12, Issue 12, pp. 47-51.

[8] MICHNA, Š., NOVÁ, I. (2008). Technologie a zpracování kovových materiálů, Adin s.r.o., Prešov.

[9] NIYAMA, E., UCHIDA, T., MORIKAWA, M., SAITO, S. (1983). A method of shrinkage prediction and its application to steel casting practice, in: AFS International Cast Metals Journal, 7(3):52-63.

[10] ŠESTÁK, J., RIEGER, F. (1998). Přenos hybnosti, tepla a hmoty, ČVUT Praha. 